\title{
Comparing men who have sex with men and inject drugs and people who inject drugs who are men and have sex with men in San Francisco: Implications for HIV and hepatitis C virus prevention
}

Adelina Artenie ${ }^{1}$, Shelley N. Facente ${ }^{2,3}$, Sheena Patel ${ }^{4}$, Jack Stone ${ }^{1}$, Jennifer Hecht ${ }^{5,6}$, Perry Rhodes $1 I^{3,7}$, Willi McFarland ${ }^{8}$, Erin Wilson ${ }^{8}$, Peter Vickerman ${ }^{1^{*}}$, Meghan D. Morris $^{4^{*}}$ *contributed equally

${ }^{1}$ Population Health Sciences, Bristol Medical School, University of Bristol, Bristol, UK

${ }^{2}$ School of Public Health, University of California Berkeley, Berkeley, CA, USA

${ }^{3}$ Facente Consulting, Richmond, CA, USA

${ }^{4}$ Department of Epidemiology and Biostatistics, University of California San Francisco, San

Francisco, CA, USA

${ }^{5}$ San Francisco AIDS Foundation, San Francisco, CA, USA

${ }^{6}$ Springboard HealthLab, Berkeley, CA, USA

${ }^{7}$ University of California San Francisco Alliance Health Project, San Francisco, CA, USA

${ }^{8}$ San Francisco Department of Public Health, San Francisco, CA, USA

Corresponding Author: Adelina Artenie

Oakfield House

Oakfield Grove

Bristol

BS8 2BN

UK

E-mail: adelina.artenie@bristol.ac.uk

Running head: COMPARING MSM-IDU and PWID-MSM

Word count: 2034

Source of Funding: AA is supported through postdoctoral fellowships through the Canadian Institute of Health Research, Fonds de recherche du Québec - Santé and Canadian Network on Hepatitis C. PV acknowledges support from the National Institute of Health Research Health Protection Research Unit in Behavioural Science and Evaluation at University of Bristol and the National Institute for Drug Abuse (NIDA; R01DA033679, R21 DA047902). The 
medRxiv preprint doi: https://doi.org/10.1101/2021.12.09.21267273; this version posted December 11, 2021. The copyright holder for this preprint (which was not certified by peer review) is the author/funder, who has granted medRxiv a license to display the preprint in perpetuity.

It is made available under a CC-BY-NC-ND 4.0 International license .

parent study, National HIV Behavioral Surveillance (NHBS), is funded by the US Centers for Disease Control and Prevention (CDC, 5U1BPS003247). The funding sources had no role in the design and conduct of this study, the collection, management, analysis, and interpretation of the data, or the preparation or approval of the manuscript.

Conflicts of interest: PV received an unrestricted research grant from Gilead that is not related to this study. SNF acknowledges consulting support from Gilead Pharmaceuticals and from End Hep C SF; neither are related to this study. All other authors have no competing interests to report. 
medRxiv preprint doi: https://doi.org/10.1101/2021.12.09.21267273; this version posted December 11, 2021. The copyright holder for this preprint (which was not certified by peer review) is the author/funder, who has granted medRxiv a license to display the preprint in perpetuity.

It is made available under a CC-BY-NC-ND 4.0 International license .

1 ABSTRACT (250 words)

2 Background: Men who have sex with men (MSM) and people who inject drugs (PWID) carry

3 a disproportionate burden of HIV and hepatitis C virus (HCV) infections. We compared the

4 demographic and risk profiles of MSM who inject drugs (MSM-IDU, i.e., men reached

5 through affiliation with MSM) and PWID who are men and have sex with men (PWID-MSM,

6 i.e., men reached through affiliation with PWID).

8 Methods: We used data from the most recent waves of the National HIV Behavioural

9 Surveillance among MSM (2017) and PWID (2018) in San Francisco. Participants were

10 recruited through venue-based (MSM) and peer-referral (PWID) sampling and completed

11 standardised questionnaires. We compared the characteristics of MSM-IDU and PWID-MSM

12 using bivariate tests.

14 Results: Of 504 participants completing the MSM survey, 6.2\% reported past-year injection 15 drug use (MSM-IDU). Among 311 male participants completing the PWID survey, 19.0\% 16 reported past-year sex with a male (PWID-MSM). Relative to MSM-IDU, more PWID-MSM 17 were older, identified as bisexual, had lower income, a history of incarceration and were 18 homeless. MSM-IDU had more male sexual partners (median: 10 vs 3) and fewer injected 19 daily (29.0\% vs 64.4\%) than PWID-MSM. While more PWID-MSM sought sterile equipment 20 from a syringe program (86.4\% vs $35.5 \%$ ), fewer reported using PrEP (15.0\% vs $42.9 \%$ ).

22 Conclusion: The sociodemographic, risk behaviour, and prevention access profiles of MSM-

23 IDU and PWID-MSM in San Francisco suggest that they represent distinct populations who 24 may require tailored HIV and HCV prevention strategies. MSM- and PWID-focused 25 prevention programs should provide combined sexual health and harm reduction messages 26 and services.

28 Key words: men who have sex with men; MSM; MSM-IDU; people who inject drugs; PWID;

HIV; hepatitis

C; $\mathrm{HCV}$ 
medRxiv preprint doi: https://doi.org/10.1101/2021.12.09.21267273; this version posted December 11, 2021. The copyright holder for this preprint (which was not certified by peer review) is the author/funder, who has granted medRxiv a license to display the preprint in perpetuity.

It is made available under a CC-BY-NC-ND 4.0 International license .

30

31

32 Men who have sex with men (MSM) and people who inject drugs (PWID) are two of the

33 populations at highest risk of HIV and hepatitis $\mathrm{C}$ virus (HCV) infection ${ }^{[1,2]}$. These

34 populations have traditionally been viewed distinctly, with research and interventions

35 generally focusing on either the sexual behaviours of MSM or the injecting behaviours of

36 PWID, despite evidence that that some MSM inject drugs (MSM-IDU) and some male PWID

37 engage in sex with other men (PWID-MSM) ${ }^{[3-7]}$. Studies among MSM have indicated that

\section{INTRODUCTION}

MSM-IDU have a greater prevalence of HIV and HCV infection, experience more socioeconomic disadvantage and have higher levels of sexual risk behaviours, in addition to also having injection-specific risks compared to MSM who do not inject drugs (MSM non-

IDU $)^{[3-5]}$. Conversely, studies among PWID who are men found that, relative to those who do not report sex with other men (PWID non-MSM), PWID-MSM have lower socio-economic stability, are more likely to engage in high-risk injection practices and to be living with $\mathrm{HIV}^{[6,}$ 7].

While previous studies have highlighted the distinct characteristics of people with dual risk behaviours relative to other MSM or PWID populations, it remains unclear how MSM-IDU and PWID-MSM compare to each other in their demographic groupings, their drug use and sexual patterns, their primary mode of HIV and HCV infection and how they may be reached. These similarities and differences are important in informing the planning and delivery of HIV and HCV prevention services and the ongoing US national and global campaigns to eliminate these viral infections as public health problems by $2030^{[1,2,8,9]}$. In the US, the third largest HIV transmission group among men is a joint risk category referred 
medRxiv preprint doi: https://doi.org/10.1101/2021.12.09.21267273; this version posted December 11, 2021. The copyright holder for this preprint (which was not certified by peer review) is the author/funder, who has granted medRxiv a license to display the preprint in perpetuity.

It is made available under a CC-BY-NC-ND 4.0 International license .

54 to as "male-to-male sexual contact and injection drug use" ${ }^{[10]}$. Yet, if MSM-IDU and PWID-

55 MSM present distinct risk behaviours, different strategies may be needed to reach each

56 group.

58 Our primary aim was to characterise similarities and differences between MSM-IDU and

59 PWID-MSM by comparing socio-demographic, injection drug use and sexual patterns, and

60 access to services. As a secondary aim, we also compared the characteristics of MSM-IDU to

61 MSM non-IDU and PWID-MSM to male PWID non-MSM, respectively, to gain a broader

62 understanding of the characteristics of these groups. Our case example is San Francisco,

63 where the burden of HIV and HCV infections is high for MSM and PWID ${ }^{[11,12]}$, campaigns to

64 eliminate these infections are ongoing ${ }^{[13,14]}$, and surveys with comparable measures for

65 these populations are available.

66

METHODS

69 We used data collected through US Centers for Disease Control and Prevention (CDC)

70 National HIV Behavioural Surveillance (NHBS) surveys ${ }^{[15]}$, which conducts behavioural

71 surveillance among key populations at risk of HIV infection. We used the most recent data

72 from San Francisco's MSM (2017) and PWID (2018) surveys. MSM were recruited using

73 time-location sampling and participants were eligible for enrolment if they were $\geq 18$ years,

74 resided in the San Francisco Metropolitan Statistical Area (MSA), and either identified as

75 MSM or had any sex with another man in the previous year ${ }^{[15]}$. The time-location sampling

76 method entailed intercepting MSM at venues where gay and other MSM congregate. PWID

77 were recruited though peer referral and were eligible if $\geq 18$ years, resided in the San 
medRxiv preprint doi: https://doi.org/10.1101/2021.12.09.21267273; this version posted December 11, 2021. The copyright holder for this preprint (which was not certified by peer review) is the author/funder, who has granted medRxiv a license to display the preprint in perpetuity.

It is made available under a CC-BY-NC-ND 4.0 International license .

78 Francisco MSA and reported past-year injection drug use ${ }^{[15]}$. The peer-referral method

79 entailed participants referring persons from their social networks who they knew to be

80 PWID.

81

82 In both surveys, participants completed an interviewer-administered electronic

83 questionnaire and were tested for HIV. Testing for HCV antibody status was only conducted

84 among PWID. HIV and HCV infection were assessed using standardized testing methods ${ }^{[15]}$.

85 The same core questionnaire was used across both surveys, which collected information

86 about socio-demographic factors, injection drug use, sexual risk behaviours and access to

87 HIV and HCV services. Participants were reimbursed $\$ 50$ for their time. Both studies were

88 approved by the institutional review boards of the University of California, San Francisco

89 and the CDC.

90

91 For this study, we restricted the PWID study sample to participants with self-reported

92 gender as men. Those who reported sex with a man in the past year were categorised as

93 PWID-MSM. Among the MSM study sample, we categorized those who reported injecting

94 drugs in the past year as MSM-IDU. We categorised the remaining groups as PWID non-

95 MSM and MSM non-IDU, respectively.

96

97 We used medians and interquartile ranges, and frequency distributions to summarise

98 continuous and categorical variables, respectively. We used Pearson's chi-square or,

99 alternatively, Fisher's Exact tests when expected cell counts were $\leq 5$ for categorical

100 variables, and Mann-Whitney $U$ tests for continuous variables to explore differences

101 between groups. All analyses were performed using SAS version 9.4. 
medRxiv preprint doi: https://doi.org/10.1101/2021.12.09.21267273; this version posted December 11, 2021. The copyright holder for this preprint (which was not certified by peer review) is the author/funder, who has granted medRxiv a license to display the preprint in perpetuity.

It is made available under a CC-BY-NC-ND 4.0 International license .

102

103 RESULTS

104

105 Of the 504 participants completing the MSM survey, 31 (6.2\%) were classified as MSM-IDU.

106 Conversely, of 464 participants completing the PWID survey, 311 (67.0\%) identified as men

107 and of these, 59 PWID (19.0\%) were classified as PWID-MSM. Their characteristics and those

108 of MSM non-IDU and PWID non-MSM are presented in Table 1.

109

110 Comparing MSM-IDU and PWID-MSM

111

112 We noted differences between MSM-IDU and PWID-MSM across most socio-demographic

113 measures. PWID-MSM were older than MSM-IDU ( $57.6 \%$ vs $35.5 \%$ were $\geq 40$ years), more

114 racially/ethnically diverse (61.0\% vs $35.5 \%$ identified as non-white) and more identified as

115 bisexual (45.8\% vs $16.1 \%$ ). PWID-MSM were also less educated and fewer were currently

116 employed relative to MSM-IDU, with a majority reporting a household annual income of less

117 than $\$ 25,000$, experiencing homelessness and having a history of detention.

118

119 Injection drug use and sexual behaviours also differed between the two groups. Relative to

120 MSM-IDU, PWID-MSM began to inject drugs earlier (median age: 22 vs 30 years), more

121 injected $\geq 2$ different drugs ( $59.3 \%$ vs $25.8 \%$ ) and injected daily (64.4\% vs $29.0 \%$ ). Conversely,

122 PWID-MSM reported fewer male sexual partners compared to MSM-IDU (median: 3 vs 10),

123 fewer reported condomless anal sex (62.7\% vs $93.6 \%)$ and more indicated having a female 124 sex partner (50.9\% vs $22.6 \%$ ). One exception to these differences was the type of drug most 
medRxiv preprint doi: https://doi.org/10.1101/2021.12.09.21267273; this version posted December 11, 2021. The copyright holder for this preprint (which was not certified by peer review) is the author/funder, who has granted medRxiv a license to display the preprint in perpetuity.

It is made available under a CC-BY-NC-ND 4.0 International license .

125 often injected, with $64.5 \%$ and $54.2 \%$ of MSM-IDU and PWID-MSM indicating

126 methamphetamine, respectively.

127

128 Some markers of service use differed between the two groups. A greater proportion of

129 PWID-MSM sought sterile syringes from a syringe service program relative to MSM-IDU

130 (86.4\% vs 35.5\%). Conversely, more MSM-IDU reported using PrEP (42.9\% vs $15.0 \%)$ and

131 having been tested for HCV (90.3\% vs 61.0\%) compared to PWID-MSM. The two groups

132 were comparable with respect to HIV testing and opioid agonist treatment. HIV prevalence

133 did not differ between the groups and was high for both MSM-IDU (32.3\%) and PWID-MSM

134 (39.0\%).

135

136 Comparing MSM-IDU and MSM non-IDU

137

138 While most MSM-IDU and MSM non-IDU identified as gay (71\% and 91\%), a larger

139 proportion of MSM-IDU identified as heterosexual (13\% vs $1 \%$ ) or bisexual ( $16 \%$ vs $8 \%$ )

140 compared to the MSM non-IDU group. Key socio-economic characteristics differed between

141 the two groups, with a larger proportion of MSM-IDU reporting having completed only high

142 school education or less (35.5\% vs $11.2 \%$ ), a household annual income of less than $\$ 25,000$

143 (38.7\% vs $16.5 \%$ ), current homelessness ( $25.8 \%$ vs $2.3 \%$ ) and a history of incarceration

144 (45.2\% vs 15.4\%) compared to MSM non-IDU. We also noted differences for some sexual

145 behaviours. More MSM-IDU received money or drugs in exchange for sex with a man (35.5\%

146 vs $5.5 \%)$ and having a female sex partner (22.6\% vs 6.6\%). A larger proportion of MSM-IDU

147 reported prior HCV testing compared to MSM non-IDU (90.3\% vs 54.6\%). HIV prevalence

148 was also higher among MSM-IDU compared to MSM non-IDU (32.3\% vs $18.4 \%$ ). 
medRxiv preprint doi: https://doi.org/10.1101/2021.12.09.21267273; this version posted December 11, 2021. The copyright holder for this preprint (which was not certified by peer review) is the author/funder, who has granted medRxiv a license to display the preprint in perpetuity.

It is made available under a CC-BY-NC-ND 4.0 International license .

149

150 Comparing PWID-MSM and PWID non-MSM

151

152 PWID-MSM and PWID non-MSM were comparable on several socio-demographic measures,

153 including age, education, employment and income. A large majority of PWID non-MSM

154 identified as being heterosexual (93.7\%), while only $15.3 \%$ of PWID-MSM did so. A smaller

155 proportion of PWID-MSM reported current homelessness (66.1\% vs $81.7 \%$ ) compared to

156 PWID non-MSM. Several injection drug use behaviours differed between the two groups. A

157 larger proportion of PWID-MSM reported methamphetamine as their primary drug injected

158 (54.2\% vs $18.3 \%$ ) and a smaller proportion reported injecting $\geq 2$ different drugs (59.3\% vs.

$15980.6 \%$ ) and injecting daily (64.4\% vs. 81.0\%) compared to PWID non-MSM. With respect to

160 testing and use of services, we found a larger proportion of PWID-MSM were aware (72.5\%

161 vs $48.3 \%)$ and had used PrEP (15.0\% vs 0.4\%) than PWID non-MSM. HIV prevalence was

162 higher among PWID-MSM compared to PWID non-MSM (39.0\% vs. 5.9\%); no difference was

163 found for HCV prevalence (71.2\% vs $79.4 \%)$.

164

165

DISCUSSION

166

167 Overall, compared to MSM-IDU, PWID-MSM presented greater socio-economic

168 disadvantage on nearly all demographic measures considered, were more likely to be

169 racially/ethnically diverse, and to indicate being bisexual rather than gay. Relative to MSM-

170 IDU, PWID-MSM appeared to have a heavier injection drug use profile but lower sexual risk

171 practices. While MSM-IDU appeared to be more engaged in MSM-oriented prevention

172 programs like PrEP, PWID-MSM were more engaged with syringe service programs, which 
medRxiv preprint doi: https://doi.org/10.1101/2021.12.09.21267273; this version posted December 11, 2021. The copyright holder for this preprint (which was not certified by peer review) is the author/funder, who has granted medRxiv a license to display the preprint in perpetuity.

It is made available under a CC-BY-NC-ND 4.0 International license .

173 have been primarily targeted towards PWID. Together, the differences observed in the

174 socio-demographic, risk behaviour and healthcare access profiles of MSM-IDU and PWID-

175 MSM suggest that they represent distinct populations that are present in different social

176 spaces and may require targeted HIV/HCV prevention strategies. More broadly, these

177 findings suggest that harm reduction and healthcare settings catering to MSM and PWID

178 need to reflect the complexity of risk that these groups face, providing a wider range of

$179 \mathrm{HIV} / \mathrm{HCV}$ prevention messages and services than is suggested by their primary risk

180 behaviour or the label that is ascribed to them.

181

182 The extent to which people who engage in both injecting- and sexual-risk behaviours were

183 included in the PWID- or MSM-focused studies could reflect the primary behaviour they

184 associated with and which takes precedence in their day-to-day life or the social and sexual

185 networks they interact with. In a qualitative research study conducted in Denver, some

186 participants reported engaging in male-to-male sex work to sustain their injection drug use

187 patterns, whereas others indicated that injection drug use was only used to enhance male-

188 to-male sex ${ }^{[16]}$. Varying motivations and levels of priority assigned to injecting and sexual

189 practices have also been reported in other studies ${ }^{[17,18]}$ and explain why some individuals

190 who engage in both behaviours may not identify as MSM or PWID ${ }^{[16]}$. A better

191 understanding of the reasons motivating these practices is needed, as it could increase the

192 extent to which HCV and HIV prevention programs engage with these populations and,

193 ultimately, their impact on minimising risk.

195 We also noted important differences between MSM-IDU and MSM non-IDU and PWID-MSM

196 and PWID non-MSM, respectively, in line with prior studies conducted among MSM $^{[3-5]}$ and 
medRxiv preprint doi: https://doi.org/10.1101/2021.12.09.21267273; this version posted December 11, 2021. The copyright holder for this preprint (which was not certified by peer review) is the author/funder, who has granted medRxiv a license to display the preprint in perpetuity.

It is made available under a CC-BY-NC-ND 4.0 International license .

$197 \mathrm{PWID}^{[6,7]}$. For example, one-third of MSM-IDU indicated receiving money or drugs from a

198 man to have sex, whereas only a minority of MSM non-IDU indicated this practice. In

199 addition, the level of HCV testing was greater in the former group. Conversely, while few

200 PWID-MSM indicated heroin as the most commonly injected drug, more than half of PWID

201 non-MSM did so. Across both MSM and PWID, HIV prevalence was higher among the dual

202 risk groups. Collectively, these findings highlight complex behavioural, service access and

203 HIV infection burden distinctions within both MSM and PWID populations, adding to the

204 importance of providing access to combined sexual health and harm reduction messages

205 rather than targeting specific risk behaviours.

206

207 The primary limitation of this study is the small sample size of MSM-IDU and PWID-MSM,

208 which limited the statistical power to detect significant differences between them. It is also

209 possible that we might have incorrectly detected significant differences due to having

210 performed multiple tests. Even so, taken together, the numerous differences observed

211 between MSM-IDU and PWID-MSM across distinct characteristics and measures support the

212 broader finding that these two groups are distinct and should not be conflated with one

213 another. Additionally, aside from HIV and HCV infection status, all other variables were

214 assessed through self-report, which are liable to misclassification errors. However, studies

215 have suggested that self-reported data in these populations are generally valid ${ }^{[19,20]}$. Finally,

216 the extent to which our findings are generalisable to MSM and PWID populations in other

217 settings is unknown and should be explored in future studies.

218

219 In conclusion, our study suggests that MSM-IDU and PWID-MSM represent different

220 populations, with distinct demographic, risk behaviour and healthcare access profiles. In 
medRxiv preprint doi: https://doi.org/10.1101/2021.12.09.21267273; this version posted December 11, 2021. The copyright holder for this preprint (which was not certified by peer review) is the author/funder, who has granted medRxiv a license to display the preprint in perpetuity. It is made available under a CC-BY-NC-ND 4.0 International license .

221 light of ongoing calls to broaden access to HCV and HIV prevention and treatment programs

222 among PWID and MSM to reach 2030 elimination goals, findings indicate a need to provide

223 access to a range of services and prevention messages to both of these populations. 


\section{REFERENCES}

1. World Health Organization. Interim guidance for country validation of viral hepatitis elimination. Geneva, Switzerland: World Health Organization, 2021. Available at: https://www.who.int/publications/i/item/9789240028395. Accessed June 2021.

2. Joint United Nations Programme on HIV/AIDS (UNAIDS). Global HIV statistics. Fact sheet 2021. Geneva, Switzerland, 2021. Available at:

https://www.unaids.org/sites/default/files/media asset/UNAIDS FactSheet en.pdf. Accessed August 2021.

3. Gorbach PM, Javanbakht M, Ragsdale A, et al. Methamphetamine Injection Among Young Men Who Have Sex With Men: Risk for Human Immunodeficiency Virus Transmission in a Los Angeles Cohort. J Infect Dis 2020; 222(Suppl 5): S471-s6.

4. O'Connell JM, Lampinen TM, Weber AE, et al. Sexual Risk Profile of Young Men in Vancouver, British Columbia, Who Have Sex with Men and Inject Drugs. AIDS and Behavior 2004; 8(1): 17-23.

5. Raymond HF, Chu P, Nieves-Rivera I, Louie B, McFarland W, Pandori M. Hepatitis C infection among men who have sex with men, San Francisco, 2011. Sex Transm Dis 2012; 39(12): 985-6.

6. Scheim A, Knight $\mathrm{R}$, Shulha $\mathrm{H}$, et al. Characterizing Men Who Have Sex with Men and Use Injection Drugs in Vancouver, Canada. AIDS Behav 2019; 23(12): 3324-30.

7. Ferreira AD, Caiaffa WT, Bastos FI, Mingoti SA, Projeto Aj UDEB, II. Profile of male Brazilian injecting drug users who have sex with men. Cad Saude Publica 2006; 22(4): 849-60.

8. U.S. Department of Health and Human Services. Viral Hepatitis National Strategic Plan for the United States: A Roadmap to Elimination (2021-2025). Washington, DC, 2020. Available at: https://www.hhs.gov/sites/default/files/Viral-Hepatitis-NationalStrategic-Plan-2021-2025.pdf. Accessed October 2021.

9. U.S. Department of Health and Human Services. HIV National Strategic Plan for the United States: A Roadmap to End the Epidemic 2021-2025. Washington, DC, 2021. Available at: https://hivgov-prod-v3.s3.amazonaws.com/s3fs-public/HIV-NationalStrategic-Plan-2021-2025.pdf. Accessed October 2021.

10. Centers for Disease Control and Prevention. HIV Surveillance Report, 2019. 2021. Available at: https://www.cdc.gov/hiv/pdf/library/reports/surveillance/cdc-hivsurveillance-report-2018-updated-vol-32.pdf. Accessed October 2021.

11. San Francisco Department of Public Health Population Health Division. HIV Epidemiology Annual Report 2020. San Francisco, CA, 2021. Available at: https://www.sfdph.org/dph/files/reports/RptsHIVAIDS/AnnualReport2020Purple 20210817Web.pdf. Accessed October 2021.

12. Facente SN, Grebe E, Burk K, et al. Estimated hepatitis C prevalence and key population sizes in San Francisco: A foundation for elimination. PLoS One 2018; 13(4): e0195575.

13. End Hep C SF. End Hep C SF Strategic Plan 2020-2022. Available at: https://secureservercdn.net/198.71.233.185/4z4.c77.myftpupload.com/wpcontent/uploads/2020/06/EndHepC 2020StrategicPlan FINAL.pdf. Accessed October 2021. 
14. Buchbinder SP, Havlir DV. Getting to Zero San Francisco: A Collective Impact Approach. Journal of acquired immune deficiency syndromes (1999) 2019; 82 Suppl 3(Suppl 3): S176-S82.

15. Centers for Disease Control and Prevention. National HIV Behavioral Surveillance (NHBS). Atlanta, GA, 2021. Available at:

https://www.cdc.gov/hiv/statistics/systems/nhbs/reports.html. Accessed October 2021.

16. Bull SS, Piper P, Rietmeijer C. Men who have sex with men and also inject drugsprofiles of risk related to the synergy of sex and drug injection behaviors. J Homosex 2002; 42(3): 31-51.

17. Bourne A, Reid D, Hickson F, Torres-Rueda S, Weatherburn P. Illicit drug use in sexual settings ('chemsex') and HIV/STI transmission risk behaviour among gay men in South London: findings from a qualitative study. Sex Transm Infect 2015; 91(8): 5648.

18. Harawa NT, Williams JK, Ramamurthi HC, Manago C, Avina S, Jones M. Sexual behavior, sexual identity, and substance abuse among low-income bisexual and nongay-identifying African American men who have sex with men. Arch Sex Behav 2008; 37(5): 748-62.

19. Darke S. Self-report among injecting drug users: a review. Drug Alcohol Depen 1998; 51(3): 253-63.

20. Fendrich M, Mackesy-Amiti ME, Johnson TP. Validity of self-reported substance use in men who have sex with men: comparisons with a general population sample. Ann Epidemiol 2008; 18(10): 752-9. 
Table 1: Socio-demographic, injection drug use and sexual behaviours, and access to services among men who have sex with men and inject drugs (MSM-IDU) or who do not inject drugs (MSM non-IDU) and men who inject drugs and have sex with other men (PWID-MSM) or who do not have sex with other men (PWID non-MSM)

\begin{tabular}{|c|c|c|c|c|c|c|c|}
\hline Characteristic & $\begin{array}{c}\text { MSM-IDU } \\
(n=31)\end{array}$ & $\begin{array}{l}\text { PWID-MSM } \\
(\mathrm{N}=59)\end{array}$ & $\begin{array}{c}\text { p- } \\
\text { valuet }\end{array}$ & $\begin{array}{l}\text { MSM non-IDU } \\
(n=473)\end{array}$ & $\begin{array}{c}\mathrm{p}- \\
\text { valuett }\end{array}$ & $\begin{array}{l}\text { PWID non-MSM } \\
(n=252)\end{array}$ & $\begin{array}{c}\text { p- } \\
\text { valuet+t }\end{array}$ \\
\hline \multicolumn{8}{|l|}{ Socio-demographic factors } \\
\hline Age & & & 0.05 & & 0.17 & & 0.14 \\
\hline $18-39$ & $20(64.5 \%)$ & $25(42.4 \%)$ & & $245(51.8 \%)$ & & $81(32.1 \%)$ & \\
\hline $40+$ & $11(35.5 \%)$ & $34(57.6 \%)$ & & $228(48.2 \%)$ & & $171(67.9 \%)$ & \\
\hline Race/ethnicity & & & $<0.01$ & & 0.58 & & 0.34 \\
\hline White & $20(64.5 \%)$ & $23(39.0 \%)$ & & $238(50.3 \%)$ & & $122(48.4 \%)$ & \\
\hline Black/African American & $1(3.2 \%)$ & $12(20.3 \%)$ & & $26(5.5 \%)$ & & $52(20.6 \%)$ & \\
\hline Hispanic or Latino/a/x & $6(19.4 \%)$ & $5(8.5 \%)$ & & $98(20.7 \%)$ & & $26(10.3 \%)$ & \\
\hline Multiple & $3(9.7 \%)$ & $17(28.8 \%)$ & & $56(11.8 \%)$ & & 43 (17.1\%) & \\
\hline Other & $1(3.3 \%)$ & $2(3.4 \%)$ & & $55(11.6 \%)$ & & $9(3.6 \%)$ & \\
\hline Sexual identity & & & $<0.01$ & & $<0.01$ & & $<0.01$ \\
\hline Heterosexual & $4(12.9 \%)$ & $9(15.3 \%)$ & & $5(1.1 \%)$ & & $236(93.7 \%)$ & \\
\hline Gay & $22(71.0 \%)$ & $23(39.0 \%)$ & & $429(90.7 \%)$ & & $2(0.8 \%)$ & \\
\hline Bisexual & $5(16.1 \%)$ & $27(45.8 \%)$ & & $39(8.3 \%)$ & & $14(5.6 \%)$ & \\
\hline $\begin{array}{l}\text { Highest level of education } \\
\text { completed }\end{array}$ & & & 0.09 & & $<0.01$ & & 0.21 \\
\hline High school or less & $11(35.5 \%)$ & $32(54.2 \%)$ & & $53(11.2 \%)$ & & $159(63.1 \%)$ & \\
\hline $\begin{array}{l}\text { Some college, Bachelor's } \\
\text { degree and above }\end{array}$ & $20(64.5 \%)$ & $27(45.8 \%)$ & & $420(88.8 \%)$ & & $93(36.9 \%)$ & \\
\hline Current employment status & & & $<0.01$ & & 0.06 & & 0.97 \\
\hline Employed & $17(54.8 \%)$ & $5(8.5 \%)$ & & $341(72.1 \%)$ & & $19(7.5 \%)$ & \\
\hline $\begin{array}{l}\text { Unable to work for health } \\
\text { reasons }\end{array}$ & $3(9.7 \%)$ & $21(35.6 \%)$ & & $16(3.4 \%)$ & & 89 (35.3\%) & \\
\hline Not employed & $11(35.5 \%)$ & $33(55.9 \%)$ & & $116(24.5 \%)$ & & $144(57.1 \%)$ & \\
\hline
\end{tabular}




\begin{tabular}{|c|c|c|c|c|c|c|c|}
\hline Household income & & & $<0.01$ & & $<0.01$ & & 0.83 \\
\hline US\$ 0 - 24,999 & $12(38.7 \%)$ & $49(83.1 \%)$ & & $78(16.5 \%)$ & & $217(86.1 \%)$ & \\
\hline US\$25,000 - 49,999 & $5(16.1 \%)$ & $7(11.9 \%)$ & & $92(19.5 \%)$ & & $24(9.5 \%)$ & \\
\hline$\geq$ US\$ 50,000 & $14(45.2 \%)$ & $3(5.1 \%)$ & & $303(64.1 \%)$ & & $11(4.4 \%)$ & \\
\hline Currently homeless & $8(25.8 \%)$ & $39(66.1 \%)$ & $<0.01$ & $11(2.3 \%)$ & $<0.01$ & $206(81.7 \%)$ & $<0.01$ \\
\hline $\begin{array}{l}\text { Ever held in detention, jail or } \\
\text { prison }>24 \mathrm{~h} \text {, past } 12 \text { months }\end{array}$ & $14(45.2 \%)$ & $53(89.8 \%)$ & $<0.01$ & $73(15.4 \%)$ & $<0.01$ & $244(96.8 \%)$ & 0.03 \\
\hline \multicolumn{8}{|l|}{ Injection drug use behaviours } \\
\hline $\begin{array}{l}\text { Age at first injection } \\
\text { (Median, IQR) }\end{array}$ & $30(23-39)$ & $22(16-30)$ & $<0.01$ & $n / a$ & $\mathrm{n} / \mathrm{a}$ & $20(16-26)$ & 0.30 \\
\hline $\begin{array}{l}\text { Drug most often injected, past } \\
12 \text { months }\end{array}$ & & & 0.53 & & & & $<0.01$ \\
\hline Meth/amphetamine & $20(64.5 \%)$ & $32(54.2 \%)$ & & $\mathrm{n} / \mathrm{a}$ & $\mathrm{n} / \mathrm{a}$ & $46(18.3 \%)$ & \\
\hline Heroin & $4(12.9 \%)$ & $13(22.0 \%)$ & & $\mathrm{n} / \mathrm{a}$ & $\mathrm{n} / \mathrm{a}$ & $148(58.7 \%)$ & \\
\hline Other & $7(22.6 \%)$ & $14(23.7 \%)$ & & $\mathrm{n} / \mathrm{a}$ & $\mathrm{n} / \mathrm{a}$ & $58(23.0 \%)$ & \\
\hline $\begin{array}{l}\text { Injected } \geq 2 \text { different drug } \\
\text { types, past } 12 \text { months }\end{array}$ & $8(25.8 \%)$ & $35(59.3 \%)$ & $<0.01$ & $\mathrm{n} / \mathrm{a}$ & $\mathrm{n} / \mathrm{a}$ & $203(80.6 \%)$ & $<0.01$ \\
\hline Daily injection, past 12 months & $9(29.0 \%)$ & $38(64.4 \%)$ & $<0.01$ & $\mathrm{n} / \mathrm{a}$ & $\mathrm{n} / \mathrm{a}$ & $204(81.0 \%)$ & $<0.01$ \\
\hline $\begin{array}{l}\text { Used injection equipment } \\
\text { previously used by someone } \\
\text { else, past } 12 \text { months }\end{array}$ & $8(25.8 \%)$ & $24(40.7 \%)$ & 0.16 & $n / a$ & $\mathrm{n} / \mathrm{a}$ & $102(40.5 \%)$ & 0.98 \\
\hline Overdose, past 12 months * & $1(9.1 \%)$ & $11(30.6 \%)$ & 0.15 & 0 & 0.30 & $64(28.1 \%)$ & 0.76 \\
\hline \multicolumn{8}{|l|}{ Sexual behaviours } \\
\hline $\begin{array}{l}\text { Number of male sexual } \\
\text { partners, past } 12 \text { months } \\
\text { (Median, IQR) }\end{array}$ & $10(6-20)$ & $3(1-10)$ & $<0.01$ & $7(2-20)$ & 0.38 & $\mathrm{n} / \mathrm{a}$ & $\mathrm{n} / \mathrm{a}$ \\
\hline $\begin{array}{l}\text { Condomless anal intercourse, } \\
\text { past } 12 \text { months }\end{array}$ & $29(93.6 \%)$ & $37(62.7 \%)$ & $<0.01$ & $381(80.6 \%)$ & 0.07 & $\mathrm{n} / \mathrm{a}$ & $\mathrm{n} / \mathrm{a}$ \\
\hline $\begin{array}{l}\text { Received money or drugs from } \\
\text { a man to have sex, past } 12\end{array}$ & $11(35.5 \%)$ & 30 (50.9\%) & 0.16 & $26(5.5 \%)$ & $<0.01$ & $\mathrm{n} / \mathrm{a}$ & $\mathrm{n} / \mathrm{a}$ \\
\hline
\end{tabular}




\begin{tabular}{|c|c|c|c|c|c|c|c|}
\hline months & & & & & & & \\
\hline $\begin{array}{l}\text { Had a female sex partner, past } \\
12 \text { months }\end{array}$ & $7(22.6 \%)$ & $30(50.9 \%)$ & $<0.01$ & $31(6.6 \%)$ & $<0.01$ & $183(72.6 \%)$ & $<0.01$ \\
\hline \multicolumn{8}{|l|}{ Testing and use of services } \\
\hline $\begin{array}{l}\text { Drug treatment, past } 12 \\
\text { months }\end{array}$ & $6(19.4 \%)$ & $18(30.5 \%)$ & 0.26 & $22(4.7 \%)$ & $<0.01$ & $70(27.8 \%)$ & 0.68 \\
\hline OAT, past 12 months* & $3(27.3 \%)$ & $16(44.4 \%)$ & 0.31 & 0 & 0.02 & $142(62.3 \%)$ & 0.04 \\
\hline $\begin{array}{l}\text { Obtained sterile needles from } \\
\text { a SSP, past } 12 \text { months }\end{array}$ & $11(35.5 \%)$ & $51(86.4 \%)$ & $<0.01$ & $n / a$ & $n / a$ & $239(94.8 \%)$ & 0.04 \\
\hline $\begin{array}{l}\text { Obtained sterile syringes from } \\
\text { a pharmacy, past } 12 \text { months }\end{array}$ & $17(54.8 \%)$ & $29(49.2 \%)$ & 0.61 & $n / a$ & $\mathrm{n} / \mathrm{a}$ & $92(36.5 \%)$ & 0.07 \\
\hline $\begin{array}{l}\text { Tested for HIV, past } 12 \\
\text { months** }\end{array}$ & $19 / 21(90.5 \%)$ & $30 / 40(75.0 \%)$ & 0.19 & $304 / 385$ (79.0\%) & 0.21 & $159 / 238(66.8 \%)$ & 0.30 \\
\hline $\begin{array}{l}\text { Tested for HCV, past } 12 \\
\text { months }\end{array}$ & $28(90.3 \%)$ & $36(61.0 \%)$ & $<0.01$ & $258(54.6 \%)$ & $<0.01$ & $187(74.2 \%)$ & 0.04 \\
\hline PreP awareness** & $18 / 21(85.7 \%)$ & $29 / 40(72.5 \%)$ & 0.24 & $373 / 385$ (96.9\%) & 0.04 & $115 / 238(48.3 \%)$ & $<0.01$ \\
\hline PreP use, past 12 months** & $9 / 21(42.9 \%)$ & $6 / 40(15.0 \%)$ & 0.02 & $171 / 385$ (44.4\%) & 0.89 & $1 / 238(0.4 \%)$ & $<0.01$ \\
\hline HIV positive & $10(32.3 \%)$ & $23(39.0 \%)$ & 0.53 & $87(18.4 \%)$ & 0.06 & $15(5.9 \%)$ & $<0.01$ \\
\hline HCV antibody positive & $\mathrm{n} / \mathrm{a}$ & $42(71.2 \%)$ & & $\mathrm{n} / \mathrm{a}$ & & $200(79.4 \%)$ & 0.17 \\
\hline
\end{tabular}

Abbreviations: $\mathrm{HCV}=$ hepatitis $\mathrm{C}$ virus; $\mathrm{IQR}=$ interquartile range; $\mathrm{SSP}=$ syringe service program; $\mathrm{OAT}=$ opioid agonist treatment;

t $p$-value comparing MSM-IDU to PWID-MSM

+† p-value comparing MSM-IDU to MSM non-IDU

$+++p$-value comparing PWID-MSM to PWID non-MSM

*Data available among participants who used opioids in the previous year only

** Data presented among participants who report being HIV-negative

Note: p-values were derived based on Pearson's chi-square test or, alternatively, Fisher's Exact test when expected cell counts were $\leq 5$ for categorical variables, and Mann-Whitney $U$ test for continuous variables 